\title{
Improving Science Literacy Skills for High School Students Through Guided Inquiry- Based Learning
}

\author{
Ernita Vika Aulia \\ Department of Science Education \\ Universitas Negeri Surabaya \\ Surabaya, Indonesia \\ ernitaaulia@unesa.ac.id
}

\begin{abstract}
The main objective of this study was to describe the effectiveness of guided inquiry-based learning to improve high school students' science literacy skills. The science literacy skills was the ability to engage with science-related issues, scientific ideas, and reflective thinking. Evaluation criteria of science literacy skills consisted of four interrelated aspects, which were context, knowledge, competence, and attitude. The guided inquiry-based learning was implemented on two class, XI IPA 2 and XI IPA 3 using one group pretest-posttest design, especially on solubility and solubility product concept. The data collection techniques used were observation, test, and questionnaire. The results of this study showed that (1) each learning phase of guided inquiry in lesson plan had been implemented well and very well. The average percentage of learning implementation was $100 \%$, meaning that all the learning steps in lesson plan I, II, and III could be performed well by teacher, (2) learning process acquired positive response from students, and (3) student's science literacy skills increased, indicated by $\mathrm{N}$-gain score at medium and high category. It could be concluded that guided inquiry-based learning was effective to improve students' scientific literacy skills.
\end{abstract} learning

Keywords - science literacy skills, guided inquiry-based

\section{INTRODUCTION}

The challenges of $21 \mathrm{st}$ century are signified by development of three skills most needed today; learning and innovation skills, skills in using information, media and technology, and skills in life and career [1]. Learning of the 21 st century uses authentic learning to direct and guide students to learn. This is in accordance with demands in the 2013 curriculum, in which learning process is authentic, thus students are required to associate what they learned with experience in everyday life.

Chemistry is a science clustered into natural sciences group, therefore chemistry has the same characteristics as natural science. Science learning is an active activity or process in studying natural phenomena using scientific processes and attitudes. The process of discovering the concept of science, especially chemistry requires work methods, attitudes, and scientific thinking to solve a problem. Meaningful chemical learning provide clarity of relationships between concepts for students. This meaningfulness can occur if students are able to connect between new knowledge and the knowledge they have before [2]. Therefore, chemical learning is expected to provide learning experience directly to students through the use and development of process skills and scientific attitudes to solve problems in everyday life [3].

The 2015 PISA report revealed that someone with scientific literation should have competences to explain phenomena, evaluate and design investigations, and interpret data and evidence scientifically [4]. Based on characteristics of chemistry lessons, especially solubility and solubility product material, the suitable method used to make meaningful learning and develop science literacy skills is a guided inquiry model. Guided inquiry learning model is a learning activity involving all students' abilities to search and investigate a problem systematically, logically, and analytically with the guidance of the teacher, thus students can formulate their own findings confidently [5]. The developed guided inquiry-based learning material is effective to be used to improve students' science literacy skills on solubility and solubility product concepts. Thus, there is a positive effect between the development of guided inquirybased learning material and the improvement of various aspects of science literacy skills for senior high school students [6].

Several studies showed that a guided inquiry learning model could improve students' science literacy skills. In inquiry-based laboratory activities, students understood concepts more meaningfully and the average score of student performance was found to significantly increase [7]. Inquirybased science literacy learning in laboratory activities enhances the science literacy skills of high school students in aspects of the content, context, process, and attitudes of students in voltaic cell material. Therefore, it could be concluded that guided inquiry learning model can make students more confident and make learning more meaningful [8]. In addition, the average score of students' conceptual understanding using guided inquiry model is higher compared to traditional teaching. Guided inquiry learning models can help students associate knowledge systems consisting of theories, enhance conceptual understanding, and encourage students to be interactive in the learning process [9]. Students was found to express a positive attitude towards the importance of science and believe that science (chemistry) is important component [10][11].

The results of a field study at Muhammadiyah High School Surabaya showed that students' science literacy skills 
still lacking. Students had not been able to answer the science literacy questions in aspects of context, competence, and knowledge properly and correctly. As many as $92 \%$ of students had not been able to formulate a problem according to the phenomenon, $84 \%$ students had not been able to formulate hypotheses, and $92 \%$ students had not been able to determine the experimental variables correctly because students were trained to determine variables only on biology subject in $10^{\text {th }}$ grade and after that, students were not trained again. As many as $44 \%$ of students had not been able to answer questions based on the table of observation correctly and $92 \%$ of students had not been able to determine conclusions correctly. Therefore, this research would implement guided inquiry-based learning on chemistry learning to improve students' science literacy skills in solubility and solubility product material.

\section{METHOD}

The subjects of this research were two classes, consisted of 40 students in $11^{\text {th }}$ grade Muhammadiyah Senior High School Surabaya in academic year 2017/2018. This research was conducted for 5 weeks from April to May 2017 using a pre-experimental research. The research design used one group pretest-posttest design [12]:

$$
\mathrm{O}_{1}{ }^{\mathrm{a}} \quad \mathrm{X}^{\mathrm{b}} \quad \mathrm{O}_{2}{ }^{\mathrm{c}}
$$

(a) $\mathrm{O}_{1}=$ Pre-test, (b) $\mathrm{X}=$ guided inquiry model-based learning, (c) $\mathrm{O}_{2}=$ Post-test

The results of learning implementation were obtained through observation using the lesson plan implementation observation sheet. The results of student responses were obtained through questionnaires using student response questionnaire sheets. The results of students' science literacy skills in aspects of context, competence, and knowledge were obtained through tests, while attitude aspects were obtained through questionnaires. Then the data that obtained were analyzed descriptively. The increase in the score of students' science literacy skills before and after learning was analyzed using N-gain, with high, medium, and low criteria [13].

\section{RESULTS AND DISCUSSION}

\section{A. The Implementation of Learning}

This data was obtained from the assessment of two observers using the lesson plan implementation observation sheet for three meetings in class XI IPA 2 and 3 . Implementation of learning diagrams in lesson plan I, II, and III are presented in Figure 1.

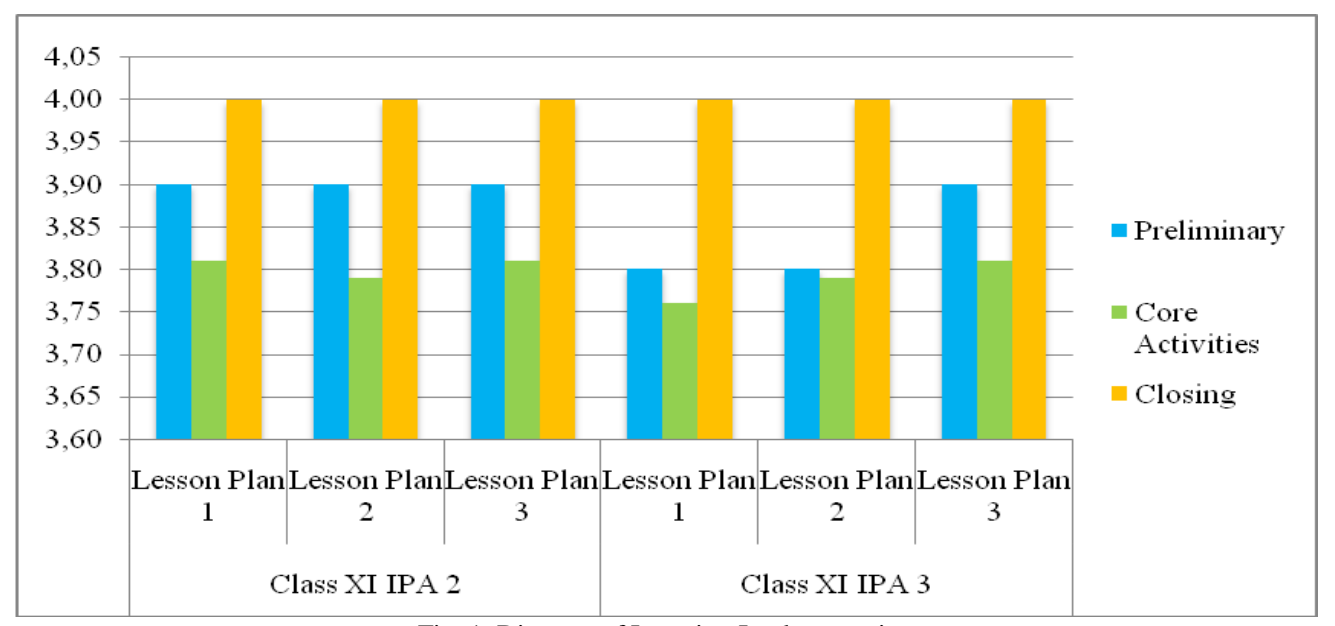

Fig. 1. Diagram of Learning Implementation

In general, the implementation of lesson plan in meetings 1,2 , and 3 obtained scores with good to very good categories because all stages of learning had been well implemented and the phases of guided inquiry learning in lesson plans have been arranged in a coherent and systematic manner. The average score of meeting 1 was lower than meetings 2 and 3 . This was because at the meeting 1 students began to learn through experimental activities to find their own knowledge never been done before, so that students needed active involvement in learning and more guidance from the teacher. The experience obtained by students at meeting 1 could be used for meeting 2 and 3 , so in general the score of the implementation of learning at meeting 3 increases. The results of this study indicated that teachers could implement and manage the learning well. The implementation of good learning would have an impact on achieving learning goals.

\section{B. Students' response}

Student responses to the implementation of guided inquiry learning were known from the answers in response questionnaire filled out by students after three meetings. The recapitulation of the student response questionnaire is presented in Table 1.

Based on the data in Table 1, it could be seen that the implementation of learning obtained good and very good (positive) response from students ( $\geq 61 \%$ with good and very good categories). This was indicated by the percentage of students' positive responses to the attractiveness of teaching materials, worksheets, learning atmosphere, the way teachers teach, and the stages directed by teachers in learning reaches the range $90 \%-100 \%$. This means that most students was very interested with learning activities. The percentage of students' positive responses to teacher explanations and guidance as well as the way teachers implement guided inquiry-based learning reached range $90 \%-100 \%$, meaning that most 
students felt very clear and very happy to follow the learning process. The percentage of students' positive responses to interests in guided inquiry-based learning was $100 \%$, meaning that all students had high enthusiasm in the learning process.

TABLE I. STUDENT RESPONSES TO GUIDED INQUIRY-BASED LEARNING

\begin{tabular}{|c|c|c|c|c|c|c|}
\hline Question & Percen & $\begin{array}{l}\text { age of Respo } \\
\text { XI IPA } 2 \\
\end{array}$ & e (\%) & Percen & $\begin{array}{l}\text { gige of Respc } \\
\text { XI IPA } 3\end{array}$ & se $(\%)$ \\
\hline $\begin{array}{l}\text { What do you think about the following } \\
\text { components? }\end{array}$ & $\begin{array}{c}\text { Very } \\
\text { Interested }\end{array}$ & Interested & $\begin{array}{c}\text { Not } \\
\text { Interested }\end{array}$ & $\begin{array}{c}\text { Very } \\
\text { Interested }\end{array}$ & Interested & $\begin{array}{c}\text { Not } \\
\text { Interested }\end{array}$ \\
\hline 1. Teaching material & 50 & 45 & 5 & 50 & 50 & 0 \\
\hline 2. Learning atmosphere & 70 & 30 & 0 & 60 & 40 & 0 \\
\hline 3. The way the teacher teaches & 75 & 20 & 5 & 40 & 60 & 0 \\
\hline $\begin{array}{c}\text { 4. Stages directed by the teacher in } \\
\text { learning }\end{array}$ & 50 & 40 & 10 & 45 & 50 & 5 \\
\hline What do you think about these things? & Very clear & Clear & Not Clear & Very clear & Clear & Not Clear \\
\hline $\begin{array}{l}\text { 1. Explanation of teacher when learning } \\
\text { takes place }\end{array}$ & 65 & 35 & 0 & 65 & 35 & 0 \\
\hline $\begin{array}{l}\text { 2. Teacher guidance when student find } \\
\text { concepts through guided inquiry-based } \\
\text { learning }\end{array}$ & 50 & 40 & 10 & 70 & 25 & 5 \\
\hline $\begin{array}{c}\text { 3. Teacher guidance when student } \\
\text { complete the worksheet }\end{array}$ & 50 & 45 & 5 & 60 & 35 & 5 \\
\hline $\begin{array}{c}\text { How do you rate how teachers use guided } \\
\text { inquiry learning? }\end{array}$ & Very good & Good & $\begin{array}{l}\text { Not } \\
\text { good }\end{array}$ & Very good & Good & Not good \\
\hline $\begin{array}{c}\text { 1. Motivate students and inform learning } \\
\text { objectives }\end{array}$ & 60 & 40 & 0 & 60 & 40 & 0 \\
\hline $\begin{array}{l}\text { 2. Linking students' initial knowledge to } \\
\text { understand the material to be given }\end{array}$ & 50 & 45 & 5 & 70 & 30 & 0 \\
\hline 3. Orient students to problems & 60 & 35 & 5 & 70 & 30 & 0 \\
\hline 4. Guiding students to write questions & 50 & 40 & 10 & 60 & 40 & 0 \\
\hline $\begin{array}{l}\text { 5. Guiding students in conducting } \\
\text { experiments }\end{array}$ & 60 & 35 & 5 & 75 & 25 & 0 \\
\hline 6. Guiding students in group presentations & 55 & 40 & 5 & 60 & 40 & 0 \\
\hline 7. Guiding students in concluding learning & 50 & 45 & 5 & 50 & 45 & 5 \\
\hline \multirow{2}{*}{$\begin{array}{l}\text { Are you interested in learning as you have } \\
\text { done in the next learning activity? }\end{array}$} & Very interest & Interest & $\begin{array}{c}\text { Not } \\
\text { interest }\end{array}$ & Very interest & Interest & Not interest \\
\hline & 75 & 25 & 0 & 80 & 20 & 0 \\
\hline
\end{tabular}

Based on the results of the questionnaire response analysis in class XI IPA 2 and 3, students were interested in learning activities with the score in very good criteria. All students expressed great interest in teaching material and the atmosphere of learning in the classroom. Students were also very interested in how to teach teachers. This was because the teacher used a guided inquiry learning model. Inquiry learning encouraged students to search and use various sources of information and ideas to improve their understanding of problems, topics and issues, so students did not just answer questions [14].

Results obtained were in line with the previous study which concluded that the guided inquiry learning model equipped with worksheet could improve the activities and student achievement in the solubility and solubility product material which includes aspects of knowledge, skills, and attitudes [15]. Other studies also had positive response from students and effectively improve academic achievement and all aspects of student attitudes [16].

\section{Students' Science Literacy Skills Improvement}

The improvement of students' science literacy skills in solubility and solubility products material was analyzed using $\mathrm{N}$-gain. Gain showed differences in students' science literacy skills before and after learning. The results of the $\mathrm{N}$-gain calculation were presented in Table 2.

Based on Table 2, the guided inquiry learning model was effective to improve students' science literacy skills because $\mathrm{N}$-gain score of all students showed medium to high category. In general, the high $\mathrm{N}$-gain score was due to stages of guided inquiry learning conducted by students in accordance with Piaget's developmental theory of assimilation, accommodation, adaptation, and equilibration, in where students were trained to connect new knowledge and initial knowledge that they have before, so that learning became more meaningful. In addition, students in guided inquiry learning were also trained to think abstractly or symbolically and solved problems through experiments [17]. Guided inquiry model-based learning had six stages (phases), each of which had different characteristics and goals. Each phase was aimed to train 2 to 4 aspects of science literacy skills. 
In general, the increase in score on all attitude indicators was because students had been trained to use scientific attitudes through guided inquiry-based learning activities carried out during three meetings, including discussion with group in identifying and formulating problems based on the given phenomenon, composing hypotheses, determining variables and conducting experiments, writing and analyzing experimental results, and formulating conclusions. In guided inquiry learning there was also scientific process of active exploration that uses critical, logical, and creative thinking skills to answer the questions posed along with scientific attitudes [18]. This result was in line with previous study which proved that there was an increase in students' science literacy skills who studied using guided inquiry learning in reaction rates material [19]. The results of other studies also proved that inquiry model design had suitable characteristics for developing students' science literacy skills [8].

TABLE II.

Calculation of NoRmalized Gain Result

\begin{tabular}{|c|c|c|c|c|c|c|c|c|c|c|}
\hline \multirow{3}{*}{ Student } & \multirow{2}{*}{\multicolumn{2}{|c|}{$\begin{array}{c}\text { Aspects of } \\
\text { Context, } \\
\text { Competence, } \\
\text { and Knowledge }\end{array}$}} & \multicolumn{8}{|c|}{ Attitude Aspect } \\
\hline & & & \multicolumn{2}{|c|}{$\begin{array}{c}\text { Student } \\
\text { attitudes } \\
\text { towards science }\end{array}$} & \multicolumn{2}{|c|}{$\begin{array}{l}\text { The importance } \\
\text { of science in life }\end{array}$} & \multicolumn{2}{|c|}{$\begin{array}{c}\text { Student } \\
\text { response to } \\
\text { science as a } \\
\text { career }\end{array}$} & \multicolumn{2}{|c|}{$\begin{array}{c}\text { Student } \\
\text { responses to } \\
\text { science learning } \\
\text { at school }\end{array}$} \\
\hline & N-gain & Category & $\mathrm{N}$-gain & Category & $\mathbf{N}$-gain & Category & $\mathrm{N}$-gain & Category & $\mathrm{N}$-gain & Category \\
\hline $\mathrm{A}$ & 0.74 & High & 0.83 & High & 0.78 & High & 0.71 & High & 0.60 & Medium \\
\hline B & 0.73 & High & 0.80 & High & 0.63 & Medium & 1.00 & High & 0.61 & Medium \\
\hline $\mathrm{C}$ & 0.57 & & 0.77 & & 0.81 & High & 0.83 & High & 0.56 & Medium \\
\hline $\mathrm{D}$ & 0.63 & Medium & 0.71 & High & 0.55 & Medium & 0.60 & Medium & 0.78 & High \\
\hline $\mathrm{E}$ & 0.69 & Medium & 0.83 & High & 0.39 & Medium & 1.00 & High & 0.67 & Medium \\
\hline $\mathrm{F}$ & 0.86 & & 0.59 & & 0.82 & High & 0.70 & Medium & 0.50 & Medium \\
\hline $\mathrm{G}$ & 0.54 & Medium & 0.59 & Medium & 0.55 & Medium & 0.50 & Medium & 0.51 & Medium \\
\hline $\mathrm{H}$ & 0.76 & High & 1.00 & High & 0.61 & Medium & 0.78 & High & 0.63 & Medium \\
\hline I & 0.66 & Medium & 0.53 & Medium & 0.62 & Medium & 0.78 & High & 0.43 & Medium \\
\hline $\mathrm{J}$ & 0.69 & Medium & 0.50 & Medium & 0.75 & High & 0.77 & High & 0.44 & Medium \\
\hline $\mathrm{K}$ & 0.65 & Medium & 0.76 & & 0.61 & Medium & 0.78 & High & 0.78 & High \\
\hline $\mathrm{L}$ & 0.58 & Medium & 1.00 & High & 0.70 & Medium & 0.70 & Medium & 0.87 & High \\
\hline $\mathrm{M}$ & 0.68 & Medium & 0.68 & Medium & 0.76 & High & 0.64 & Medium & 0.71 & High \\
\hline $\mathrm{N}$ & 0.65 & Medium & 0.71 & High & 0.51 & Medium & 0.56 & Medium & 0.44 & Medium \\
\hline $\mathrm{O}$ & 0.64 & Medium & 0.77 & & 0.69 & Medium & 0.71 & High & 0.47 & Medium \\
\hline $\mathrm{P}$ & 0.68 & Medium & 0.85 & High & 0.69 & Medium & 0.67 & Medium & 0.65 & Medium \\
\hline Q & 0.57 & Medium & 0.59 & Medium & 0.66 & Medium & 0.60 & Medium & 0.33 & Medium \\
\hline $\mathrm{R}$ & 0.83 & High & 1.00 & High & 0.73 & High & 1.00 & High & 0.62 & Medium \\
\hline$S$ & 0.88 & High & 1.00 & High & 0.64 & Medium & 0.44 & Medium & 0.48 & Medium \\
\hline $\mathrm{T}$ & 0.63 & Medium & 0.66 & Medium & 0.58 & Medium & 1.00 & High & 0.55 & Medium \\
\hline
\end{tabular}

\section{CONCLUSION}

Guided inquiry-based learning was effective to improving science literacy skills in aspects of context, competence, knowledge, and all indicators of attitude aspects with medium and high $\mathrm{N}$-gain scores, as well as student scores of all attitudes indicators increased to good and very good categories.

\section{ACKNOWLEDGMENT}

The author would like to thank observer who assesses the implementation of learning, headmaster and chemistry teacher of Muhammadiyah Senior High School Surabaya who has allowed and assisted this research.

\section{REFERENCES}

[1] B. Trilling and C. Fadel, " $21^{\text {st }}$ Century Skills: Learning for Life in Our Times," San Francisco: John Wiley \& Sons, Inc, 2009.

[2] R. W. Dahar, "Teori-Teori Belajar \& Pembelajaran," Jakarta: Erlangga, 2011.

[3] Mulyasa, "Menjadi Guru Profesional: Menciptakan Pembelajaran Kreatif dan Menyenangkan,” Bandung: PT Remaja Rosdakarya, 2013.

[4] OECD, "PISA 2015 Assessment and Analytical Framework: Science, Reading, Mathematic and Financial Literacy," Paris: OECD Publishing, 2016.

[5] W. Gulo, "Strategi Belajar Mengajar," Jakarta: PT Gramedia, 2008.

[6] E. V. Aulia, S. Poedjiastoeti, and R. Agustini, "The Effectiveness of Guided Inquiry-based Learning Material on Students' Science Literacy Skills,” J. Phys.: Conference Series, vol. 947, 2018. 
[7] B. A. Sesen and L. Tarhan, "Inquiry-Based Laboratory Activities in Electrochemistry: High School Students' Achievements and Attitudes," Res. Sc. Educ., vol. 43, pp. 413-435, 2013.

[8] A. Rakhmawan, A. Setiabudi, and A. Mudzakir, "Perancangan Pembelajaran Literasi Sains Berbasis Inkuiri pada Kegiatan Laboratorium," Jurnal Penelitian dan Pembelajaran IPA (JPPI), vol. 1, pp. 143-152, 2015.

[9] N. Gültepe and Z. Kiliç, "Scientific Argumentation and Conceptual Understanding of High School Students on Solubility Equilibrium and Acids and Bases," J. Turkish Sc. Educ., vol. 10, pp. 5-21, 2013.

[10] K. Salta and C. Tzougraki, "Attitudes Toward Chemistry Among 11 th Grade Students in High Schools in Greece," Sc. Educ., vol. 88, pp. 535-547, 2004.

[11] J. Menis, "Attitudes towards School, Chemistry and Science among Upper Secondary Chemistry Students in the United States," Res. Sc. Tech. Educ., vol. 7, pp. 183-190, 1989.

[12] S. Arikunto, Prosedur Penelitian, Jakarta: Rineka Cipta, 2010.

[13] R. R. Hake, "Interactive Engagement Versus Traditional Methods: A Six Thousand Student Survey of Mechanics Test Data for Introductory Physics Courses," Amer. J. Phys., vol. 66, pp. 64-74, 1998.
[14] C. Kuhlthau, et al., Guided Inquiry: learning in the $21^{\text {st }}$ century, London: Libraries Unlimited, Inc, 2015.

[15] H. Setiowati, A. Nugroho, and W. Agustina, "Penerapan Model Pembelajaran Inkuiri Terbimbing (Guided Inquiry) Dilengkapi LKS untuk Meningkatkan Aktivitas dan Prestasi Belajar Siswa pada Materi Pokok Kelarutan dan Hasil Kali Kelarutan Kelas XI MIA SMA Negeri 1 Banyudono Tahun Pelajaran 2014/2015," Jurnal Pendidikan Kimia (JPK), vol. 4, pp. 54-60, 2015.

[16] E. Ural, "The Effect of Guided-Inquiry Laboratory Experiments on Science Education Students' Chemistry Laboratory Attitudes, Anxiety and Achievement," J. Educ. Train. Studies, vol. 4, pp. 217-227, 2016.

[17] R. E. Slavin, Psikologi Pendidikan: Teori dan Praktik, Jakarta: PT Indeks, 2011.

[18] D. Llewellyn, Teaching High School Science Through Inquiry, Amerika: Corwin Press, 2005.

[19] Pratika and Muchlis, "Penerapan Model Pembelajaran Inkuiri Terbimbing pada Materi Laju Reaksi untuk Melatihkan Kemampuan Literasi Sains Siswa Kelas XI SMAN 1 Gondang Tulungagung," UNESA Journal Of Chemical Education, vol. 5, pp. 9-18, 2016. 